УДК 94 (575.3)

ББК 63.3 (5 Тад)

\title{
Гражданская война в Республике Таджикистан и ее влияние на миграционные процессы
}

\author{
С.Ф. Назариоева
}

Алтайский государственный университет (Барнаул, Россия)

\section{The Civil War in the Republic of Tajikistan and Its Impact on Migration}

S.F. Nazarshoeva

Altai State University (Barnaul, Russia)

Рассматриваются исторические события 1992-1997 гг. в Республике Таджикистан, известные как гражданская война или межтаджикский конфликт, его политические и социальные корни и влияние, оказанное этими событиями на миграционные процессы в стране. Анализируется изменение состава населения государства в ходе конфликта и в процессе репатриации беженцев в последующие годы. Кроме позитивных сдвигов, достигнутых правительством Республики Таджикистан в процессе репатриации беженцев из Таджикистана и правительствами других стран СНГ в ходе их интеграции в состав населения, также рассматривается ряд негативных социально-экономических последствий конфликта, продолжающих оказывать влияние на социальное и экономическое положение в Таджикистане. При написании данной статьи автор опирался на Статистический ежегодник Республики Таджикистан, обзоры и исследования Агентства $\mathrm{OOH}$ по делам беженцев, материалы периодической печати Республики Таджикистан, а также на важнейшие исследования на английском, русском и таджикском языках. В заключение делается вывод о том, что гражданская война в Республике Таджикистан явилась фактором, оказавшим наиболее значительное воздействие на миграционные процессы в регионе. Многие негативные последствия данного вооруженного конфликта и сегодня продолжают сказываться на социально-экономическом состоянии Таджикистана.

Ключевые слова: гражданская война, межтаджикский конфликт, идентичность, миграция, беженцы, репатриация.

DOI 10.14258/izvasu(2019)6-13
The article is devoted to the historical events of 1992-1997 in the Republic of Tajikistan, known as the civil war or the inter-Tajik conflict, its political and social roots and the impact that the events had on migration processes in the country. It analyzes the change in the structure of the state's population during the conflict and in the process of repatriation of refugees in subsequent years. In addition to the positive changes achieved by the Government of the Republic of Tajikistan in the process of repatriation of refugees from Tajikistan and the governments of other CIS countries during their integration into the population, the article also considers a number of negative socioeconomic consequences of the conflict, which continue to affect the social and economic situation in the Republic of Tajikistan. While writing this article, the author relied on the Statistical Yearbook of the Republic of Tajikistan, surveys and studies of the UN Refugee Agency, materials of the periodical of the Republic of Tajikistan, as well as on the most important studies in English, Russian and Tajik. In conclusion, it is determined that the civil war in the Republic of Tajikistan was the factor that had significant impact on migration processes in the region. Many of the negative consequences of this armed conflict today continue to affect the socio-economic condition of the Republic of Tajikistan.

Key words: civil war, inter-Tajik conflict, identity, migration, refugees, repatriation. 
В течение многих веков региональная миграция проходила как через Таджикистан, так и внутри Таджикистана, вдоль торговых путей Великого шелкового пути и в горных районах. До образования Таджикской ССР таджики как этническая группа не имели единой идентичности, говорили на разных персидских диалектах. После распада СССР ислам сохранял свою важность, но для многих жителей Таджикистана доминирующей формой самоидентификации стала традиционная социальная принадлежность авлоду, или клану. Принадлежность населения Республики Таджикистан данной форме устойчивых механизмов социальной организации определила характер будущего конфликта. В Таджикистане возникла сложная клановая война среди регионально разрозненных кланов.

В целом гражданская война в Республике Таджикистан 1992-1997 гг. довольно широко освещается в работах иностранных авторов, таких как А. Эрлих [1], Р.Х. Роланд [2], таджикских авторов (Р.А. Абулхаев [3], М.Б. Бабаханов [4], Ш.С. Саъдиев [5]), российских авторов (В.И. Бушков, Д.В. Микульский [6]) и др. Однако аспект влияния гражданской войны в Республике Таджикистан на миграционные процессы довольно слабо изучен. Исходя из этого автором данной статьи была поставлена цель оценить влияние, оказанное гражданской войной в Республике Таджикистан на характер миграционных процессов.

С окончанием существования СССР в Республике Таджикистан, как и в других постсоветских республиках, начался процесс перехода от одного общественно-политического строя к другому. Практика постсоветского периода, за исключением прибалтийских республик, показала, что в таких ситуациях обостряется борьба за власть, правящие круги не хотят расставаться с ней, а претенденты разной политической ориентации стремятся получить ее любыми методами и средствами. В результате общество оказывается втянутым в политическое противостояние, которое в Республике Таджикистан в силу различных внутренних и внешних причин и особенностей перешло в военное противоборство [6].

Принятие законов «О языке» от 22 июля 1989 г. [7], «О государственном суверенитете Таджикской Советской Социалистической Республики» от 24 августа 1990 г. [8], «Об общественных объединениях в Таджикской ССР» от 8 декабря 1990 г. [9], заявление Верховного Совета «О государственной независимости Республики Таджикистан» от 9 сентября 1991 г. [10] и другие факторы способствовали ускоренной политизации общественной жизни в Таджикистане, активизировали национальное самосознание, создали правовую базу для организации и деятельности общественных движений и партий, которые начали вести активную борьбу за власть. Однако эти процессы имели ряд негативных моментов.
Во-первых, к тому времени стало ясно, что республика не вполне готова к самостоятельному развитию. Во-вторых, не была решена проблема равного доступа к верховной власти. В-третьих, продолжали набирать силу процессы эрозии центральной власти и появления новых центров власти. В-четвертых, республика испытывала мощное политическое и информационное давление внешних сил. Как и многие другие бывшие советские республики, страна столкнулась с экономическими, экологическими и социальными проблемами.

Вооруженные столкновения между отрядами оппозиции и силами, поддерживавшими правительство, приобретали все более систематический, кровопролитный и криминализированный характер. Конфликт по существу разрастался в широкомасштабную гражданскую войну. Внутренняя нестабильность в Республике Таджикистан, обострение на таджикско-афганской границе и опасность эскалации грозили стать взрывоопасными для всего среднеазиатского региона [11].

Начавшаяся в 1992 г. из-за протестов на выбоpax гражданская война (широко распространенное название которой - «межтаджикский конфликт») привела к эмиграции большинства этнических меньшинств и массовым демографическим потрясениям. За короткий промежуток времени были утрачены многие экономические и социально-культурные достижения, которые были накоплены в течение предшествующего периода развития. Все это негативным образом повлияло на масштабы бедности населения страны. Приводимые в статистическом сборнике «Финансы Республики Таджикистан» за 2000 г. данные показывают размеры нанесенного войной экономического ущерба, составившего свыше 7 млрд долларов США [12, с. 18]. После обретения независимости и начала гражданской войны бедность охватила не только регионы, которые непосредственно пострадали, находясь в театре военных действий, но почти все население Республики Таджикистан. В категорию «новых бедных» попали не только люди, не имеющие образования и специальности, но и большинство образованных людей. Это прежде всего учителя, врачи, инженеры, ученые.

Гражданская война 1992 г. стала причиной вынужденного перемещения населения внутри страны и его эмиграции за ее пределы. Темпы миграции в регионе конфликта резко возросли. Около миллиона человек (это каждый шестой гражданин Республики Таджикистан) стали переселенцами. Из них примерно 250 тыс. человек покинули страну, а около 700 тыс. стали мигрантами в пределах Республики Таджикистан [4, с. 111].

Данная миграция имела в основном три направления: первое - движение внутри страны, с юга на север, в столицу и Горно-Бадахшанскую авто- 
номную область (ГБАО); второе - республики Казахстан, Кыргызстан, Туркменистан, Узбекистан и Российская Федерация; третье - Афганистан, Иран, Пакистан и арабские страны.

Таким образом, политические трансформации и гражданская война как следствие распада единого Советского государства повлекли за собой резкий социально-экономический кризис, сопровождавшийся падением производства и массовой безработицей, что привело к массовому оттоку переселенцев из осваиваемых ими районов и усилению миграционных процессов в бывших союзных республиках.

Верность кланам определила первое направление, в котором перемещались беженцы внутри страны. Так, многие этнические таджики вернулись в свои горные деревни. В одной лишь Хатлонской области каждый четвертый житель покинул родной дом. Известны отдельные случаи, когда было вынуждено бежать все население того или иного кишлака. Люди бежали из зон, охваченных войной, в более или менее безопасные места. Большинство из них пытались найти убежище в местах их этнического происхождения. Так, в Горно-Бадахшанскую автономную область (ГБАО) прибыло около 56 тыс. мигрантов. В Ленинабадскую область (ныне Согдийская обл.) переселились почти 35 тыс. человек. По данным Управления Верховного комиссара Организации Объединенных Наций по делам беженцев (УВКБ $\mathrm{OOH),} \mathrm{за} \mathrm{это} \mathrm{время} \mathrm{в} \mathrm{Таджикистане} \mathrm{было} \mathrm{переме-}$ щено от 500 до 600 тыс. человек, а от 20 до 40 тыс. человек были убиты. От 60 до 75 тыс. таджиков бежали в Афганистан, многие утонули, пытаясь пересечь реку Пяндж [1].

Тюрко- и русскоязычные жители страны также покидали Республику Таджикистан во время гражданской войны, многие из них не вернулись. Оценка эмиграции этих групп может быть получена из численности беженцев в различных странах, которые эти группы считают этнической родиной. Их отток сформировал второе направление перемещения беженцев из Республики Таджикистан. В течение многих лет эти беженцы вызывали напряженность в регионе, поскольку другие экономически отстающие страны Центральной Азии считали, что не могут справиться с их притоком. Тем не менее ситуация значительно улучшилась за последние пятнадцать лет.

Во время гражданской войны в Таджикистане Республика Казахстан была одним из первых государств, принявших десятки тысяч беженцев. По некоторым оценкам, их число составило около 6 тыс. человек. Однако эти данные весьма приблизительны [13]. Большая их часть была натурализована и сменила гражданство на гражданство Республики Казахстан.

По состоянию на 1997 г. правительством Республики Кыргызстан было зарегистрировало около 16700 беженцев из Таджикистана, а также дополнительно сообщалось о более чем 28 тыс. незарегистрированных переселенцах из этой республики, многие из них считались экономическими мигрантами. Хотя более 7 тыс. из этих беженцев, включая большинство этнических таджиков, вернулись в Таджикистан, примерно 9 тыс. человек, почти все этнические киргизы, не изъявили желания вернуться [14, с. 22]. Местная интеграция этих беженцев была облегчена благодаря двустороннему соглашению между республиками Кыргызстан и Таджикистан, которое позволяет гражданам Республики Таджикистан отказаться от своего гражданства и стать гражданами Республики Кыргызстан. Уже к 2003 г. 5 тыс. киргизских таджиков получили киргизское гражданство; еще 1 тыс. человек сделали это в 2004 г. В настоящее время в Республике Кыргызстан натурализована подавляющая часть беженцев из Республики Таджикистан [1].

Приблизительно 20 тыс. жителей Таджикистана, преимущественно этнических туркмен, в 1990-х гг. бежали в Туркменистан. УВКБ ООН сообщило, что в 2005 г. президент Туркменистана Сапармурат Ниязов предоставил гражданство всем беженцам, проживавшим в Туркменистане с 1999 г. Эти общины, которым туркменские власти предоставили землю вокруг столицы (Ашхабад), хорошо интегрировались в принимающем государстве и были признаны приносящими положительный экономический эффект в местных сообществах [3, с. 78].

Таджикские узбеки - самая сложная группа беженцев. В Республике Узбекистан насчитывается около 39200 беженцев, в основном этнических узбеков-таджиков, которые до 2006 г. были зарегистрированы «джентльменским соглашением» с УВКБ $\mathrm{OOH}$ (Республика Узбекистан не является участником Конвенции ООН 1951 г. о статусе беженцев, или Протокола 1967 г.), пока УВКБ ООН не было вынуждено покинуть эту страну. Это число, безусловно, не измеряет общий отток узбекских таджиков в Республику Узбекистан. Более того, по переписи 2000 г. трудно определить, сколько узбеков покинули Республику Таджикистан, так как считается, что многие из тех, кто был зарегистрирован в качестве узбеков во время переписи 1989 г., были зарегистрированы в этнических группах, не предусмотренных переписью СССР 1989 г. К ним относятся такие племенные группировки, как лакаи или конграты. Таджикские узбеки, возможно, также реклассифицировали себя как этнических арабов или таджиков [1].

Крупнейшим и наиболее значительным оттоком из Республики Таджикистан в связи с начавшимся военным конфликтом был отток русскоязычного населения. Это население начало покидать Центральную Азию еще в 1960-х гг. из-за потери им привилегированного положения в среднеазиатских 
республиках СССР; стандарты высшего образования для этнических таджиков позволили таджикам занять много важных государственных должностей. Некоторые русскоязычные жители Республики Таджикистан вернулись в Россию или переехали в другие бывшие советские республики. Массовый исход русскоязычного населения, однако, не происходил до провозглашения независимости Республики Таджикистан и начался в связи с небезопасной обстановкой в стране в результате начавшейся гражданской войны. Хотя в Российской Федерации и существовал закон о беженцах с 19 января 1993 г., однако в период с 1993 по 1999 г. статистический учет прибывавших в Россию беженцев осуществлялся слабо, поэтому трудно измерить точную численность вернувшегося на историческую родину из Республики Таджикистан русскоязычного населения. Тем не менее не вызывает сомнений тот факт, что большая его часть оказалась именно в Российской Федерации.

Хотя с 1997 г. правительство Республики Таджикистан выражало желание, чтобы русскоязычное население оставалось, его отток продолжался. По оценкам, представленным в информационной записке о Республике Таджикистан Федерального исследовательского управления Библиотеки Конгресса США, количество русскоязычного населения в Таджикистане в результате эмиграции сократилось на 75\% к первоначальному его числу (по данным 1989 г.); более того, к 2000 г. русскоязычное население составило всего 1,1\% населения Таджикистана (68171 человек) по сравнению с 7,6\% в 1989 г. (388480 человек) [1]. В результате сократилось городское население Таджикистана, поскольку русскоязычное население составляло четверть городского населения.

Большинство других небольших некоренных этнических групп также покинули Республику Таджикистан в ходе гражданской войны. Этнические немцы воспользовались немецкими законами, которые разрешали им переезжать в Германию, согласно переписи 2000 г. в Республике Таджикистан осталось только 1136 этнических немцев. С 1989 по 2006 г. 10890 евреев иммигрировали в Израиль, согласно переписи 2000 г. в стране осталось только 197 евреев. Татары также массово покидали Таджикистан, причем крымские татары в основном возвращались на свою исконную родину в Крым; другие татары уехали в Российскую Федерацию, некоторые в Республику Татарстан РФ [2].

Что касается третьего направления перемещения беженцев из Республики Таджикистан, то первоначально на территорию Афганистана перешло около 75 тыс. чел., однако впоследствии 30 тыс. самостоятельно вернулись обратно через Амударью, многие в Горный Бадахшан. В мае 1993 г. под эгидой УВКБ ООН беженцы из Республики Таджикистан начали возвращаться из северного Афганистана в свои дома в Хатлонской области. УВКБ ООН организовал процесс добровольной репатриации беженцев на основе предварительного соглашения с правительствами республик Афганистан, Таджикистан и Узбекистан. По состоянию на конец 1997 г. в Афганистане оставалось 18900 беженцев из Республики Таджикистан, незначительное количество которых также было зарегистрировано в Иране, Пакистане и других арабских странах [13].

Положение в Таджикистане стабилизировало достигнутое в 1997 году соглашение о национальном примирении между Правительством Республики Таджикистан и оппозиционными силами [15]. Частью соглашения был «Протокол о беженцах» [16]. Протокол помог реинтегрировать беженцев, пожелавших вернуться домой. Закон, который помог временно перемещенным лицам (ВПЛ) вернуть свою утраченную в ходе конфликта собственность (дома многих вынужденных переселенцев оказались занятыми к моменту их возвращения), сделал этот процесс более плавным. По данным УВКБ ООН, в 2006 г. в Таджикистане уже не было временно перемещенных лиц (ВПЛ), и практически все таджикские беженцы были репатриированы из Афганистана.

Что касается этнических меньшинств, покинувших Республику Таджикистан во время гражданской войны, то большая их часть не вернулась в Таджикистан, о чем свидетельствует первая перепись населения страны, проведенная в 2000 г. Хотя в республике национальность не является критерием измерения чистой миграции, перепись показывает, что в период с 1989 по 2000 г. в Таджикистане в составе населения значительно преобладали этнические таджики: 79,9\% в 2000 г. по сравнению с 62,3\% в 1989 г. Одной из причин этого может быть возврат из Республики Узбекистан большой группы этнических таджиков, точная численность которой неизвестна, но по некоторым оценкам она составляет от 100 до 200 тыс. человек [2]. Эти данные, однако, очень неточные, так как на сегодняшний день некоторые узбеки считают себя таджиками. Даже с учетом высокого уровня рождаемости среди таджиков изменение состава населения, по мнению большинства наблюдателей, можно объяснить только эмиграцией этнических меньшинств.

По данным исследования, проведенного Верховным комиссариатом ООН по делам беженцев и Международным комитетом Красного Креста (МККК), и дополненным информацией правительства Таджикистана, около одного миллиона человек стали переселенцами [4, с. 111]. Подсчитать же количество репатриантов не представляется возможным ввиду крайней приблизительности данных и большого разрыва в их оценках, представленных в источниках. 
В результате трансформационных процессов и гражданской войны в Республике Таджикистан резко возрос уровень бедности. Это одна из наиболее острых проблем страны. Бедность стала социально-политическим дестабилизирующим фактором. Также, помимо социальной напряженности, значительную роль в формировании потоков трудовой миграции в Республике Таджикистан играет демографический фактор. Республика относится к числу стран с высокими темпами роста населения. Демографические процессы стали серьезным препятствием на пути восстановления экономики и ускорения темпов ее развития. Таким образом, демографическая ситуация в Республике Таджикистан тоже способствует росту безработицы и бедности населения. В совокупности эти факторы в основном и определяют сейчас миграцию трудовых ресурсов.

По данным статистического агентства, с 1997 по 2002 г. уровень безработицы в Республике Таджикистан составлял от 2,3 до 3,2\% от общего числа населения страны [14, с. 64]. Но эти цифры явно занижены. Учитывая проблему демографии, связанной с увеличением роста населения, и проблему экономического кризиса, связанного со спадом производства, такие цифры не реальны. По данным Всемирного банка, число безработных в республике в 2000 г. достигало около $30 \%$ [17, с. 6].

В книге Х. Умарова и Р. Ульмасова приводятся иные данные о числе безработных. Авторы считают, что эти данные вызывают сильные сомнения, поскольку огромное количество работников числятся в списках, но находятся в вынужденном отпуске уже в течение многих лет. По их мнению, уровень безработицы равняется 59\% (2004 г.). Естественно полагать, что такая безработица не могла не вызвать массовую внешнюю трудовую миграцию [18, с. 18].

Хотя после подписания соглашения между Правительством Республики Таджикистан и Объединенной таджикской оппозицией в 1997 г. и наблюдалась стабилизация политической ситуации и смягчение остроты социально-экономического кризиса и последствий гражданской войны, проблема бедности населения в Республике Таджикистан не была решена [19]. Снижение уровня бедности в Таджикистане в основном было связано с развитием внешней тру- довой миграции и переводами трудовыми мигрантами, работающими за границей, денег в Таджикистан. Заработки трудовых мигрантов являлись важнейшим источником дохода для населения.

За первые 15 лет после провозглашения независимости Республика Таджикистан превратилась из государства внутренне перемещенных лиц и беженцев в одного из региональных лидеров по экспорту рабочей силы. Тем не менее и сегодня в Таджикистане сохраняется много разных миграционных моделей, и страна одновременно остается крупным экспортером рабочей силы, страной транзита, страной, направляющей беженцев.

За свою короткую историю государственной независимости Таджикистан испытал на себе множество форм миграции, однако гражданская война 1992-1997 гг. может по праву считаться историческим событием, оказавшим наиболее значительное воздействие на миграционные процессы в регионе. Правительству Республики Таджикистан потребовались годы, чтобы вернуть большую часть беженцев и вынужденных переселенцев обратно в Таджикистан и минимизировать последствия вооруженного конфликта. Опыт Республики Таджикистан в области урегулирования вопросов, связанных с внутренними перемещениями населения, и вопросами репатриации беженцев имеет большое значение для политиков и правительственных чиновников, чья деятельность прямо или косвенно связана с управлением миграционными потоками в стране.

Что касается трудовой миграции, то именно с 1997 г., после подписания Общего соглашения о национальном примирении между Правительством Республики Таджикистан и Объединенной таджикской оппозицией (ОТО), миграционная ситуация в республике охарактеризовалась ростом внешней трудовой миграции. В настоящий момент именно эта миграция является фактором, стабилизирующим перенасыщенность внутреннего рынка труда и рост социальной напряженности (за счет поступающих в Республику Таджикистан денежных средств от внешних трудовых мигрантов), что, несомненно, оказывает положительное воздействие на экономику республики в целом.

\section{Библиографический список}

1. Erlich A. Tajikistan: From Refugee Sender to Labor Exporter // Migration Policy Institute. 2006. 1, Jul. URL: https://www.migrationpolicy.org/article/tajikistan-refugeesender-labor-exporter.
2. Rowland R.H. National and Regional Population Trends in Tajikistan: Results from the Recent Census // Eurasian Geography and Economics, 2005. URL: https:// www.researchgate.net/publication/250170298_National_ 
and_Regional_Population_Trends_in_Tajikistan_Results_ from_the_Recent_Census.

3. Абулхаев Р.А. Из истории трудовой миграции Таджикистана в конце XX — начале XXI вв. Душанбе, 2014.

4. Бабаханов М.Б. История таджиков мира. Душанбе, 2005.

5. Саъдиев, Ш.С. Точикистон: рохи сулх ва ризоияти милли. Душанбе, 2002.

6. Бушков В.И., Микульский Д.В. Анатомия гражданской войны в Таджикистане (этносоциальные процессы и политическая борьба, 1992-1995). URL: http://yakov. works/libr_min/02_b/ush/kov_12.htm.

7. О языке : Закон Таджикской Советской Социалистической Республики // Медийное право. URL: http:// medialaw.asia/document/-261.

8. Декларация о государственном суверенитете Таджикской Советской Социалистической Республики. URL: http://www.gorby.ru/userfiles/tadgikistan.pdf.

9. О политических партиях : Закон // Садои мардум. Душанбе, 1998. 4 дек.

10. О провозглашении государственной независимости Республики Таджикистан : Постановление Верховного Совета Республики Таджикистан от 9 сентября 1991 г. № 392 // Adlia. Министерство юстиции Респуб- лики Таджикистан. URL: http://www.adlia.tj/show_doc. fwx?Rgn=125273.

11. Country Profile: Tajikistan, January 2007 // Library of Congress - Federal Research Division. URL: https://www. loc.gov/rr/frd/cs/profiles/Tajikistan-new.pdf.

12. Финансы Республики Таджикистан : статистический сборник. Душанбе, 2000.

13. U.S. Committee for Refugees World Refugee Survey 1997 - Tajikistan // The UN Refugee Agency (UNHCR): US Committee for Refugees and Immigrants. 1997. 1, Jan. URL: https://www.refworld.org/docid/3ae6a8bb40.html.

14. Статистический ежегодник Республики Таджикистан. Душанбе, 2003.

15. Общее соглашение об установлении мира и национального согласия в Таджикистане // Народная газета. 1997. 4-11 июля.

16. Протокол по вопросам беженцев // Бизнес и политика. 1997. 24-31 янв.

17. Республика Таджикистан: Обновленная оценка бедности. Документ Всемирного банка. Душанбе, 2006.

18. Умаров Х., Ульмасов, Р. Внешняя трудовая миграция в Таджикистане. Душанбе, 2006.

19. Холбобоев Ф.С. Борьба с бедностью остается важнейшей задачей политики нашего правительства // Бизнес и политика. 2004. 4 ноября. 